indefeasibility it guarantees. Clearly it contemplates the situation where there is a registered owner whose title is being challenged by a third party, in particular a claimant under a previously registered or caveated interest which in consequence of fraud or error has been removed from the register. It does not contemplate the challenge of a registered owner's interest by another registered owner of the same land.

Of course, this would not be so if the plea of prior certificate of title did not require two currently registered titles. If there were two titles, one registered and one cancelled, Section 167 would govern to protect the person who "is registered as owner." However, this view only reinforces Egbert J.'s first conclusion that there must be concurrent titles. Section 167 governs a competition between a registered certificate and a prior cancelled certificate, but as between competing current certificates, sections 63,65 and 180 prevail.

If our suggested interpretation of the plea of prior certificate of title is correct, it would be possible to argue that Egbert J. relied upon section 167 in support of his conclusion that there must be concurrently existing certificates of title for the plea of a prior certificate of title to succeed, rather than as negating the plea altogether. It may be suggested that his use of the word "moreover" indicates that this was his meaning although such a view would be hard to reconcile with his unequivocal statement that section 167 gives full protection except in the one case of misdescription. Technically, it could be argued that his comments on this section were obiter in any event as he had already concluded on the basis of sections 63,65 and 180 that there must be two certificates in existence which, on the facts, he found, there were not. $^{12}$

-G. J. DAVIES*

- R. J. HARRISON**

12 Supra, n. 2 at 585.

- Lecturer in Law, Australian National University.

* Assistant Professor of Law, University of Alberta.

\title{
MAXIMS AND SUGGESTIONS FOR CRIMINAL TRIAL JUDGES
}

The mood and temper of the public with regard to the treatment of crime and criminals is one of the most unfailing tests of the civilization of any country. A calm, dispassionate recognition of the rights of the accused, and even of the convicted, criminal against the State-a constant heart-searching by all charged with the duty of punishment-a desire and eagerness to rehabilitate in the world of industry those who have paid their due in the coinage of punishment: tireless efforts towards the discovery of curative and regenerative processes: unfailing faith that there is a treasure, if you can only find it in the heart of every man. [Winston Churchill] ${ }^{1}$

Many newly-appointed trial Judges experience difficulty and are more than a little apprehensive when faced with their first criminal trials. Some continue to experience difficulty throughout their judicial careers, particularly with respect to sentencing a convicted offender. Most trial Judges can be heard to say that sentencing offenders is the most difficult and delicate task that is entrusted to them. This is under- 
standable, since the Canadian system of judicial selection is such that the appointee is almost totally unprepared and ill-equipped to discharge the awesome duty of sentencing a fellow human being. Some appointments to the Provincial Court Bench, where ninety per cent of all criminal matters are handled, include those who have had little or no criminal trial experience. Indeed, this same lack of experience is evident throughout the trial courts.

It would seem reasonable and most desirable to institute a form of training for all newly-appointed trial Judges before being permitted to preside over a criminal trial. This is particularly necessary with respect to sentencing. Failure in this regard is not only most unfair to the new Judge but can also be unjust to the accused.

In the absence of such a system of training, the following maxims and suggestions are offered with the hope that they may fall into the hands of the newly-appointed Judge and be of some value to him. It is also hoped that they may be of some assistance to the experienced trial Judge in reminding him of matters that he knows well but which may occasionally be overlooked under the pressures of a long and fatiguing day.

Much of the material which follows is taken from Russell's The Magistrate. Most of the maxims set out by Sir Alison Russell are appropriate to the Canadian system of criminal justice and are therefore set out verbatim. Some have been enlarged upon or varied where this seemed appropriate. The object in setting these maxims before the reader is the perhaps presumptuous hope that the quality of criminal justice in Canada will be improved. Judges are entrusted with great powers and these powers must be exercised with the utmost restraint and discretion. Only then will Canadians have the necessary confidence and trust in our legal system which will allow it to flourish as part of a democratic system of government. The Judge must always remember that he is dealing with a fellow human regardless of the crime found to have been committed and, in punishing him, that the calm, dispassionate recognition of his rights, as Churchill stated, must prevail and be obvious to all. Finally, justice must be cloaked throughout with mercy. The maxims and suggestions follow.

1. Never attempt to evade responsibility in your judicial decisions.

2. Never convict a person of proven bad character unless you are satisfied beyond all reasonable doubt that he has committed the offence with which he is charged.

3. Never hesitate to acquit a person against whom the evidence is insufficient, even though you may feel in your mind that he is guilty.

4. Never hesitate to convict a person and punish him reasonably in accordance with the established principles of sentencing, if the evidence proves that he or she is guilty beyond all reasonable doubt, whatever his or her social position may be.

5. Never go outside the evidence in a case.

6. Never give a decision with an eye on the Court of Appeal, the Press or anybody or anything save the law and the evidence.

7. Never discuss a case beforehand and never allow it to be discussed beforehand in your presence, however trivial the charge may be or however well-intentioned a person who wishes to see you may be. 
8. Never hesitate to consult those of your colleagues with greater experience than yourself as to points of law.

9. Never fail to enter your court exactly at the time appointed for the sittings of the court. Always bear in mind that witnesses are present in court in response to a Court Order (the subpoena) and are there to perform a public duty often at considerable personal inconvenience and loss of income. They are entitled to the utmost consideration and the most courteous treatment by the court. Counsel too, are there and no doubt wish to return to their offices as soon as may be convenient after their case has been disposed of.

10. Never become angry or excited on the Bench, whatever the provocation. Never forget that a Judge is master in his court and that an unperturbed demeanour controls a refractory counsel, litigant or witness.

11. Never be sarcastic to anyone but especially to a young convicted offender about to be sentenced. To do so is to invite the offender to reply in kind with the result that the Judge may feel compelled to deal with the same as contempt in the face of the court or retaliate by increasing the punishment or by ignoring the remark. The Judge who adopts any one of these three alternatives will gain little public support or respect since the exchange could have been avoided in the first place and will be avoided if the Judge will remember that he is dealing with a fellow human being.

12. Never be overly humorous on the Bench and never so at the expense of an accused or a witness. A little innocent humor sometimes relieves a highly tensed atmosphere but it is a good rule ordinarily to avoid humor. A joke will not be recollected with amusement by a defeated or convicted party.

13. Never hurry; take your time. You will not impress the public by anxious haste, but you will do so by a dignified deliberation in your proceedings.

14. Never forget that what may be routine work to you may be new and strange to the accused. Try to remember at all times that both the accused and the witnesses may never have had any previous contact with the court system and may never again. Yet their impressions of the Canadian court system will be formed for their lifetime by what they observe on that one occasion.

15. Never forget that though a case may be of a simple kind and one of a number of similar simple cases before the court for hearing, yet, no doubt, it is of importance to the accused and appears to him to be worthy of serious attention; the "knock-'em-off" style may appear to be highly efficient and understandably desirable to some bored court workers but this style in trying cases is to be deprecated. Time saved may be justice spoiled.

16. Never forget that each accused brought before you is presumed innocent until proved guilty and, in exercising your discretion in granting bail, that presumption must not be overlooked. Also reasonable bail must not be denied to an accused without just cause. ${ }^{2}$ In determining what is reasonable bail, a Judge must consider the financial and social circumstances of the accused. An accused must

2 Canadian Bill of Rights, S.C. 1960, c.44, 8. 2(f). 
never be penalized by his poor circumstances and, consequently, if the Judge is not otherwise bound to deny bail, he must release the accused on Personal Recognizance Bail. A Judge must not-think that this latter type of bail is to be used solely for relatively minor offences and for certain types of accused but is a type of bail permitted by the highest court of our country, the Parliament of Canada, for use in many cases in determining what is reasonable bail. Remember that most people charged with criminal offences come from the least affluent sections of any community, and what may well be reasonable in moderately affluent circumstances may be wholly unreasonable and wholly unattainable to a less affluent accused. (The New Bail Act, when proclaimed, should overcome many of the present bail shortcomings, but will only do so if Judges will insist upon following the spirit and intent of the legislation. The new legislation would have been totally unnecessary if Judges had exercised their discretion in favor of the poor under existing legislation.)

17. In sentencing a person to pay a fine, always try to assess such fine to meet the ability of the accused to pay the fine considered, as well as the time to be served in prison in default of the payment of the fine. To mete out a fine of the same amount for the commission of an offence to all, regardless of financial circumstances, is to render a greater punishment to the poor simply for being poor. And to impose an excessive jail term in default of payment of the fine is again a manoeuvre to over-penalize the poor. While the stereotyped fine for all will permit a disposition of a large case-load with despatch, it is not to do justice. Surely it is the doing of individual justice that is the most important part of the Judge's duties, and not the disposition of a large case-load.

18. Time to pay must always be considered for each accused sentenced to pay a fine, and it is the Judge's duty to ask each accused if he requires time to pay if he does not personally request time. Many accused and certainly first offenders are inhibited from saying anything in the strange atmosphere of the court room, and sometimes are too stunned after hearing the penalty imposed to think rationally.

19. In determining the length of a jail sentence, never consider what the remission time might be nor when the convicted offender might become eligible for parole. Neither of these matters has anything to do with the sentencing Judge. If the prison authorities are permitted to remit any portion of a sentence, it is their prerogative permitted by Parliamentary enactment and may or may not be granted depending on the prisoner's behaviour and conduct while in prison. So, too, with the Parole Board, a prisoner may or may not be released after a given period by the Parole Board but whether he is or is not is of no concern to the sentencing court and to assess a term of imprisonment for the purpose of thwarting an earlier eligibility date is wrong and unjust.

20. Never forget that justice must not only be done but must appear to be done. To best ensure that this is done, in each case, the Judge should consider how he would like to be treated and dealt with if he were so unfortunate as to be in the accused's position. Do unto others as you would have them do unto you. 
21. Never be discourteous or ill-tempered or impatient with young, inexperienced counsel but rather be as helpful to them as is possible. The Judge should remember that he was once a young, inexperienced counsel himself.

22. The Judge should always give reasons for his decisions, whether they be for conviction or acquittal. Perhaps, in the failure to give any or any adequate reasons for their decisions, some Judges feel that the less they say in rendering judgment the less chance there is for a successful appeal. To adopt this attitude is to corrupt the course of justice and the rule of law. No Judge, worthy of the name, would deliberately do anything that stands in the way of or otherwise prevents justice according to law from being done. Indeed, the Judge who believes sincerely in the judgment rendered will welcome a review by the Court of Appeal.

23. A Judge should never punish a convicted offender in an exemplary fashion. If he does so he is not only punishing the offender for the offence committed by him but also for similar offences committed by others. This is most unfair and unjust.

24. The Judge should avoid the tendency to warn publicly that henceforth he intends to deal more harshly with offenders convicted of a certain offence. When this is done the Judge will find within a short time, perhaps even the next day, that someone is before him whom he cannot sentence as warned. Not all offenders are "of no fixed address."

25. Whenever the Judge considers that a jail sentence is justified for any convicted offender, it is ordinarily good practice as well as a safeguard, to remand the matter for a week or so for the purpose of obtaining a pre-sentence report. With the aid of this document and in the less demanding atmosphere of the Judge's own chambers, he will be able to think of all the principles of sentencing as they apply to that case calmly, and dispassionately. In this way, the Judge will more likely impose sentences that are both fair and appropriate far more often than if done on the spur of the moment. By so doing, time, of course, is required but needless to say, time saved may be justice denied. The Solicitor-General of Canada has reported that the Canadian Federal Penitentiary population stands at 7,500-all serving sentences of two years to life-and this notwithstanding the good work being done by the National Parole Board in effecting early releases. It has also been stated that Canada has a greater prison population per capita than any other Western nation. If this statement is true, can it be assumed that our people are less lawabiding than other people, or could it be that the quick and easy route in sentencing is perhaps one reason why our jail population is so high? The trial Judge should ponder this question well because some Canadians and especially the young are no longer content to assume that all is well within the court system as Canadians in the past may have done. It is simply not good enough for the Judge to slavishly follow what has been done in the past and sentence offenders to jail by drawing a term out of one's head after only a few moment's reflection. No Judge possesses sufficient wisdom to summarily sentence a convicted offender for an offence of a serious nature. The convicted person has rights, and since his future is at stake he is certainly entitled to much thought by the trial Judge 
as to what sentence can do the most good for him. If Judges are concerned about the reformation of the offender as many say they are, and if they are concerned with the prevention of crime to protect society, as many Judges say they are, then they must show that these concerns are genuine by taking the necessary time to explore all avenues open to them with respect to sentence. If all other alternatives appear inappropriate or unacceptable and jail becomes necessary then the Judge must seriously give thought to the period to be imposed, together with what institutions would best serve to do the most good. If this were done in all cases, it would seem only reasonable that our jail population would be drastically reduced. The money saved in prisoner care might be better spent in opening more courts to permit an improved form of justice to be practised.

26. It is no shame for a sentencing Judge to be compassionate, merciful, tolerant, and understanding when considering the forthcoming loss of freedom of a fellow citizen who has erred. Some in the community will not be happy that you possess such virtues, but this is to be expected.

27. The Judge should avoid the tendency to sit too long in court. To concentrate on the evidence and to deal with all the matters that arise during the course of a trial takes its toll with the resultant loss of mental capacity to absorb. About four hours is the limit, i.e. four hours of actual court time excluding short adjournments. To go beyond this time is to do neither side a service and certainly is a disservice since it is most important that the Judge hear and consider all the evidence in order to render a fair and just decision with reasons.

28. The Judge should always ensure that an unrepresented accused is aware of his right to counsel before plea, and his right to apply for bail forthwith if he is in custody. The Judge should assist the unrepresented accused in making the bail application by asking him pertinent questions in order to determine appropriate bail, and ensure that the accused understands the offence which he is accused of having committed. If the accused has a complaint to make regarding treatment at the hands of the police, either at time of arrest or pending first court appearance, he should be encouraged to state the nature of his complaint and injuries, if any. This enables the prisoner to make his complaint at the first opportunity and it will be taken down by the court reporter. The Judge must not make any comment as to the content of the complaint but must advise the accused that he should consult with a lawyer upon his release from jail, or, failing that, to file his complaint with the Police Commission. If he cannot for some just cause be released on bail, in this way, at least, his complaint will be preserved and, should he retain counsel, it will be available to the latter upon request from the court reporter. The Judge should, if it appears that the accused will not be represented, direct the reporter to prepare two copies of the complaint for forwarding to the Chief of Police and the Police Commission chairman. The Police Department will wish to take immediate steps to investigate the complaint and if there is merit in the complaint the Police Department may deal with the offending officer. This is the only way a police force can maintain a good public image. For a judge to refuse to allow a prisoner to state his 
complaint is to give the impression that the court is on the side of the police and the prosecution, which is already a widely held view by many people from the poor and defenseless class.

29. As soon after appointment as is possible, the Judge should make every effort to visit the jails within his jurisdiction, both Provincial and Federal, and to do so annually. It is only in this way that the Judge can know what each jail has to offer prisoners who will be sent there. It is only in this way that the Judge can determine the most good that can be achieved as a result of any given jail term. It is not good enough to listen to what others say is available; the Judge must have first-hand knowledge. It is said by some Judges that they don't wish to visit jails because they will be given a conducted tour of the institution by the Warden and will be shown only what he wishes to show them. In this way they will gain a wrong impression of the institution. This type of thinking cannot be supported by the evidence. The Judge should make a point of talking with inmates on his tour as well as with ex-inmates whenever the opportunity arises. Their statements about prison life can be verified by probation officers, councillors and the like. The Judge should find all this helpful in wrestling with future sentences, particularly with respect to the age-old principle of deterrence in sentencing. Deterrence is important to the individual concerned but often this can be accomplished by various methods of sentencing. With some, a relatively short jail term coupled with probation upon the expiration of the sentence will suffice. With others, probation alone can accomplish the same goal. With others a fine commensurate with earning ability, either with or without probation, may achieve this goal. Again, with the hardened criminal, only a term of imprisonment may be justified, and even then it is doubtful if deterrence will be achieved. It should never be forgotten that the hardened criminals are a small minority of the total charged with criminal or quasi-criminal offences. Deterrence to others is unproven historically and it is more than doubtful if it is as effective as the courts have maintained over the past century and a half. What is known for certain is that people who do commit crimes do not consider the probable consequences before committing the crime. At best, deterrence to others is speculative and perhaps wishful thinking.

30. The Judge should never sentence forthwith for a contempt in the face of the court. At least a short cooling-off period should be the rule. This will give the offender the chance to consider what he has done in the heat of the moment and may prompt an apology. The Judge will also be able to assess the wrong coolly and calmly and when he re-convenes court he may be able to accept an apology as being sufficient. The Judge should remember that he is not only the accuser but the Judge in his own cause. If punishment is to be imposed it must be done with great restraint and must not be revengeful or retaliatory.

At all times the Judge should act in such a way that he will maintain the independence, dignity, status, and impartiality of the judiciary. By always so acting the Judge will gain the respect of most with whom he comes in contact and he will have earned the confidence the people 
of Canada have reposed in him. A Judge can receive no greater compliment than to have members of the Bar and public say of him that he is just and fair.

-JOHN C. COUGHLAN*

*Judge of the Provincial Court of Alberta.

\section{MAINTENANCE OF WATER QUALITY-ALBERTA'S LEGISLATIVE SCHEME AND THE COMMON LAW}

On the first of November, 1971, the Clean Water Act came into force in the Province of Alberta. It and the Clean Air Act which became effective at the same time marked one step in a program of governmental reorganization and legislative enactment aimed at providing an efficient, effective means of controlling and eliminating the problems created by exploitation and/or misuse of the environment. There can be little doubt that the impetus for such a program was provided by the ever-increasing public concern over pollution of both air and water by human and industrial contaminants, the adverse effects of which are most pronounced in those areas of industrial and population concentration having the greatest political influence. It is therefore probable that another aim of this program was to assuage these potentially powerful segments of the populace.

It is axiomatic that the powers conferred upon an agency by legislative enactment are only as effective as the agency which enforces these powers. Only future events can indicate how effective the Alberta legislation and the agencies which administer it will be and whether the primary aim of the legislators will be to deal with problems of pollution or simply to mollify the public. The purpose of this comment is to examine the legislation dealing with water pollution, to point out certain weaknesses inherent therein, and to outline the alternative means of dealing with water pollution available at common law to riparian owners should future events prove that placating the public was the true purpose.

\section{Legislation}

Water pollution has been defined as: ${ }^{1}$

. . . any alteration of the physical, chemical, biological, or aesthetic properties of waters, including change of the temperature, taste, or odour of the waters, or the addition of any liquid, solid, radio-active, gaseous or other substance to waters or the removal of such substance from the waters, which will render or is likely to render the waters harmful to the public health, safety, or welfare, or harmful or less useful for domestic, municipal, industrial, agricultural, recreational or other lawful uses, or for animals, birds or aquatic life.

In Alberta, the following eight acts ${ }^{2}$ contain provisions dealing with water pollution as so defined:

1 The Water Authority Act, S.P.E.I. 1965, c.19, 8.2(g).

2 Although other enactments contain provisions which indirectly affect water pollution, they do 80 only in. cidentally, while the enumerated statutes contain provisions directly concerned with the problem. 